Logos Universality Mentality Education Novelty, Section:

Economical and Administrative Sciences

ISSN: 2284-5984 (print), ISSN: 2284 - 5984 (electronic)

Covered in: CEEOL, Index Copernicus, Ideas RePeC, EconPapers, Socionet

\title{
ETHICS - A FORM OF MARKETING FOR THE TOURISM BRAND OF BUCOVINA
}

\section{Liliana HÎNCU}

Doi: http://dx.doi.org/10.18662/lumeneas.2015.0201.03

Logos Universality Mentality Education Novelty, Section:

Economical and Administrative Sciences, 2015, Volume II, Issue 1, pp: $25-37$

Published by:

Lumen Publishing House

On behalf of:

Lumen Research Center in Social and Humanistic Sciences 


\title{
Ethics - a Form of Marketing for the Tourism Brand of Bucovina
}

\section{Liliana HîNCU ${ }^{1}$}

\begin{abstract}
The Internet offers enough sources for us to make a decision regarding the best place to spend our holidays; a simple search enables us to read the customers' reviews regarding a certain guesthouse, monastery, leisure place, etc. Since today we live in a society that allows us to get any information from the Internet or certain social network pages, we believe it is very important for the marketing strategies to deal with ethical behaviour. Besides the buman resources and other strategies of attracting customers, ethics is a particularly important aspect of marketing, which is subsequently able to make the difference between success and failure in business. We believe that ethics provides customers with confidence, especially if the focus is laid on certain periods of the year, when the Romanians coming from abroad wish to spend a few days in Bucovina or when the foreign tourists fascinated by the beauty of our landscapes choose to spend a few days in the same area. The aim of this paper is to outline the importance of ethics within the actions of promoting and attracting tourists for the Bucovina tourism brand.
\end{abstract}

Keywords: Tourism brand, ethics, Bucovina, business, marketing.

1 Teacher at high school -College Andronic Motrescu, Town Rădăuți, Country-Romania, liliana_hincu@yahoo.com.

Hincu, L. (2015). Ethics - a Form of Marketing for the Tourism Brand of Bucovina. Logos Universality Mentality Education Novelty, Section: Economical and Administrative Sciences, II (1), 25-37. Doi: http://dx.doi.org/10.18662/lumeneas.2015.0201.03 


\section{Introduction}

The Bucovina area provides the tourist with spectacular lanscapes alongside a string of monasteries founded by rulers and men of reknown (the Muşatin ruling familiy, Alexandru cel Bun, Ştefan cel Mare, Petru Rareş, Ştefan Tomşa, Alexandru Lăpuşneanu ans so forth), each of them painted in a specific color: the Voroneț Monastery (blue), the Humor Monastery (red), the Sucevița Monastery (green), the Moldovița Monastery (yellow) and the Arbore Monastery (a combination of various colours). Some of these monasteries are part of the UNESCO heritage and in 1976 have received the prize "Pomme d'Or" of the FIJET International Organization for their cultural and tourist value. The administrative center of the areas is the town of Suceava which can be the starting point for visiting several tourist attractions, such as the memorial house in Stupca of the Romanian composer Ciprian Porumbescu, the Vatra Dornei spa/balneology resort, the Rarău mountains (with the "Pietrele Doamnei" limestone special reserve) and the Slătioara secular forest. Most of Bucovina is covered by mountains and hills with plenty of vegetation. Altitudes are higher in the western part of the area (the Eastern Carpatioan mountains): the Rarău mountains - 1653m in altitude, the Giumalău mountains - $1857 \mathrm{~m}$ in altitude, the Obcinele Bucovinei gentle hills which step down to $300-400 \mathrm{~m}$ in the East, the Călimani mountains (the South-West of the area) is the highest volcanic complex in the Carpathian Mountains in Romania (the Pietrosu Peak in the Călimani mountains - 2102 m altitude) and, at the same time, the „youngest” mountains in our country.

Here a complex reserve with the purpose of protecting fauna and flora (many rare species such as: the edelweiss, the bison, the grouse, the lynx, the stag and so on) was established. The climatic conditions are favourable for tourism throughout the year; the heavy winter snows falling in the mountain area are favourable for winter sports, horse-drawn sleigh rides and so forth. Among the tourist attractions of Bucovina, monasteries occupy a primary place; they are true masterpieces of religious art built during the feudal period.

\section{Regional development of the Bucovina area}

The tourism potential of the Bucovina area is not sufficiently capitalized and the existing tourist services are not diversified and in this 
case the flow of tourists is ahead of the tourist facilities existing in Bucovina. There is a number of tourism development projects for Bucovina aiming at developing tourism, all included in the program "Gold Bucovina" initiated by the Ministry of Tourism since 2000. In the year 2003 the project" Stefan cel Mare 500" came as a proposition, a project entirely dedicated to the historical and religious locations in County Suceava, held in 2004 to commemorate the 500 years since the death of the great Voivod Stefan cel Mare. Important manifestations were organized in every monument erected during the reign of the Voivod Stefan cel Mare and especially Putna Monastery, events which resulted in "waves" of hundreds of thousands of tourists. The Romanian state has granted the sum of 1,800,000,000 for this program. Another project called "Modernization and development of the tourism infrastructure in Bucovina" meets the need of perfected infrastructure, both for the summer season and the cold season. The project benefits from a grant of around two million euros from the European Union granted through PHARE 2000. All these programs share a number of goals. The rich and varied potential of Bucovina imposed an increasingly wider range of equipment and organization measures to meet the requirements of modern tourism. Bucovina is an important tourist destination where certain forms of tourism can be developed: mountain tourism, eco tourism, cultural tourism, spa tourism, religious or educational tourism.

Petru Luhan presented the first five programs intended to develop tourism in County Suceava:

- "Branding and promotion for the County Suceava";

- "Development of sightseeing in Bucovina";

- "Standards and guidelines for landscaping and architecture";

- "Tourism infrastructure in County Suceava";

- "Turismul - a chance for local economic development";

- "Tradition and authenticity in Bucovinei through tourism".

Each program contains several projects such as creating a brand for Bucovina, the rehabilitation of the Suceava Fortress, promoting initiatives such as "Christmas in Bucovina", Religious tourism" or "Easter in Bucovina", the rehabilitation of the Suceava County Museum - a historical monument, the rehabilitation of the Wood Art Museum located in Cîmpulung Moldovenesc, the Bucovina BIOLAND project - eco-tourism promoting traditional products, the development of the Airport in Salcea and the implementation of the National Centre for Information and Tourist Promotion in the town of Suceava. Also, the establishment of tourist routes 
such as: the „Path of Ştefan cel Mare”, the „Road of the Tatars”, the „Salt Road", the „Monastery Tour”, the „Milk Road”, „Jacob's Route” from Viena to Suceava and to Cernăuți, Neolithic Roads - the Cucuteni Culture and Civilization (Iasi - Cucuteni - Piatra-Neamt - History Museum in Suceava) was also discussed.

The initiators of these projects aimed at meeting the requirements of their projects until 2013. Incidentally, all these goals included in the programs of tourism development, especially the religious tourism must be supported by an effective advertising campaign, both at county and country level as well as abroad.

\section{Tourist destination: Bucovina}

Rating

The concept of tourism product appears to be related both to the offer of travel agencies as well as the tourist areas, such as Bucovina, Maramures, the Danube Delta (also known as the "Delta") (Nedelea, 2003). They have become true Romania's tourist brand. Regarding the tourism brand, it represents that image element that identifies the goods or services of a given area tourism generating a feeling of pride of the local inhabitants alongside recognition and satisfaction among consumers (Nedelea, 2009).

The travel branding is the creation and maintenance of a brand in the hospitality industry, all the methods through which an organization or a product symbolizes and stands out in relation to its audience. (Nedelea, 2009). The tourism branding is to identify and then create the sustainable exploitation of competitive advantages, (in our case is about the strengths of product - the Bucovina tourist area) (Nedelea, 2009). We are dealing with a process of developing a tourism product, its release of the national and international tourism market and especially the connection between the consumer and product based upon the quality or the "uniqueness" thereof.

In order for the mountain area of the County Suceava county to have year round events to attract tourists, it is required that the main resorts in the county organize festivals in every season. Thus, for the winter, the crown of Vatra Dornei will organize the "Winter Festival", an event that takes place over eight weeks comprising various concerts and winter sports competitions.

Thus all events will attract tourists in the three mountain resorts of County Suceava throughout the year. Bucovina does not stand only for 
monasteries; it can also provide mountain tourism, recreation or wellness tourism. The business tourism is now on a growing trend and many large firms or professional associations organize meetings, conferences and congresses in the area.

\section{Identifying differentiation elements of a tourist destination}

As we know, the culture and the art form the basis of the whole knowledge and cultural tourism of all tourist areas. According to this statement we believe the culture of Bucovina has high property values, namely:

- Etnographic values which can be visited in the ethographic museums in Vatra Dornei and Gura Humorului;

- Technical values which can be visited in the Folk Museum Techniques of Bucovina located in Rădăuți);

- Artistic values which can be visited at the Art Museum of Wood located in Câmpulung Moldovenesc;

- The „Ion Grămada” ethnographic collection;

- The „spoons and towels” collection of the Professor Ion T, Tugui;

- The painting collection "George Cotos" from the Folk Customs Museum in Gura Humorului and the medieval art collections (embroidery, manuscripts, miniatures, silvering, icons, sculptures in wood and stone) at the Putna and Moldoviţa monasteries.

The competitve advantages of this area are:

A. natural tourism potential;

B. cultural and historical tourism potential;

\section{A. The natural tourist potential is represented by:}

a. The geological objectives:

- The paleonthologic reserve paleotologica "Klippa Triasica" of the Paraul Cailor river (downstream of Fundul Moldovei): protection is provided to block of fossilized red limestone where numerous fossils were found (approximately 100 species) some unprecedented in the Romanian Carpathian mountains.

- The „Formațiunea cu Aptychus” geological reserve - in Pojorâta: here numerous examples of aptychus dating back approximately 140 million years were found in red, purple and green limestone. 
- The „Piatra Pinului” geological reserve located near the town of Gura Humorului; here there almost a complete succession of olicocene that can be visited. A fossil specimen with a length of 1.8 $\mathrm{m}$ was also found here.

b. Flora objectives - are searched not only by specialists but also by tourists eager to broaden their knowledge and who love the beauty of nature. In Bucovina there are three reservations that stand out, true living museums of rare plants, namely:

- The „Lucina” Reserve - includes the Găina bog located at $1200 \mathrm{~m}$ altitude. Here, in aswamp stretching on an area of about one hectare there are a few relict dwarf birches from the Glacier age; (Hîncu 2015a).

- The „Răchitişul Mare” Reserve (south of the village of Bena). The reknown of the reserve comes from the glaciar relict called „strugurele ursului” (the bear's grape), a species of bush cohabitating with the cranberries and the blueberries in a forest of spruce and birch;

- The „Cimirna” Reserve - near the Cimirna hamlet, for the safeguarding of the „Trientales Europae” a rare plant in Europe.

c. Fauna objectives - The forest reserves are yest to be established although the laws need to be issued for the old forests. We must add that there are two dendrological reserves:

- The Dendrologic Park in the town of Gura Humorului with an area of 22 hectars and over 500 wood species (mostly exotic).

- The arboretum located in the town of Câmpulung Moldovenesc.

\section{B. The cultural and historic tourism potential is so rich that could withstand a major tourist activity.}

It highlights the intense experience of history and the great artistic sensibility of the local people, which managed to artistically shape everything that the nature has provided to them. Among the components of the local environment, the stone and wood became the main materials due the abundance and durability over time and they were transformed into immortal works of art, harmoniously situated in the landscape of Bucovina, offering them status of vast open-air museum. 


\section{a. FORTRESSES}

- The Suceava Fortress.

In the eastern part of the toen of Suceava there is the Fortress which occupies a dominant position on a high plateau. The Fortress was first mentioned in documents in 1388 and it was built of stone at the end of the $\mathrm{XIV}^{\text {th }}$ century.

- The hermitage of Daniil Sihastrul.

In the vecinity of the Putna Monastery at the foot of a wooded hill lies the hermitage of Daniil Sihastru, dug into a massive rock. Here the hermit Daniil Sihastru lived. He was an advisor of the Voivod Ştefan cel Mare.

- The Royal Inn.

The Royal Inn building was built in the early XVII ${ }^{\text {th }}$ century of stone and brick. The valuable secular architectural monument has been housing the Ethnographic Museum of Bucovina since 1968, which was refurbished in 1982 in its current form.

\section{b. MUSEUMS}

- The National Museum of Bucovina.

The exhibition presents the ancient past of this part of the country through a rich thematic heritage, various documents and archaeological items which demonstrates the continuity of the Romanian people in Bucovina.

- The Ciprian Porumbescu museum.

The museum building has become an architectural monument exhibit documents and objects that belonged to the author of the famous "Ballad" and the first Romanian operetta called "Crai Nou" . The museum heritage contains over 250 musical works and the piano that belonged to the composer Ciprian Porumbescu.

\section{c. MEMORIAL HOUSES}

- The Ciprian Porumbescu memorial house

The house that belonged to the composer's parents and where the composer was born constitutes a place of pilgramage and the local cultural authorities organize guided tours.

The house was designed and various objects were gathered and put together in order to bring witnesses related to the life of Ciprian Porumbescu as a child and student, his family environment and so on. 
- The parental home of the poet Nicolae Labis.

\section{d. MONASTERIES}

- The Voronet Monastery, located at 4 kilomenter south of the town of Gura Humorului is the most representative monastery for the architecture style typical for the region of Moldova; it harmonizes in an original way elements of the Gothic style with elements of the Byzantine style. (Hîncu, 2015a).

- The Humor Monastery built on the $15 \mathrm{~km}$ long near the locality bearing the same name and located 7 kilometers away from the town of Gura Humorului founded by the Chancellor Teodor Bubuioc and his wife Anastasia.

- The Moldoviţa monastery

Dedicated to the "Annunciation", the Moldovița Monastery was built by the Voivod Petru Rareş in the year 1532 and its painting ended five years later in the year 1537.

- The Sucevița Monastery

The Suceviţa Monastery dedicated to the "Resurrection" was built during the last decades of the XVI ${ }^{\text {th }}$ century through the contribution of the entire Movilă noblemen family.

- The Putna Monastery the first and the most important foundation of the great Voivod Ştefan cel Mare between 1466-1469 is located where legend has it the arrow released from the bow of the brave voivod has stopped.

\section{Ethical notions concerning the promotion of the „Bucovina,, tourism brand}

\section{Ethics within tourism companies}

Every enterprise has a certain responsibility in economic and social terms and this is a standpoint acknowledged by all the managers of the business world. But this responsibility is perceived differently. Almost all areas of social life, were introduced ethical regulations, which were institutionalized by including various codes of professional ethics(Sandu, 2012).

Codes of ethics have been made to ensure the smooth course of the organization, both ethically and administrative presented in a more or less explicit rules to be observed not only by the public system employees but 
also by employees of travel companies. These may be the basis for behaviour patterns of tourism employees thus outlining professional standards of work in tourism (T,igu, 2003).

As regards the economic side, there are two approaches to ethics:

- the classical approach - companies exist to benefit their owners and to reduce certain costs;

- the social and economic approach - maximizing the company profit is the second priority and the first priority is ensuring its survival. The companies are legal entities registered in one country and must comply with the legal and business climate of the country in which it operates. The company's timeframe is long, so it must pursue long-term economic results and to this end it will accept some social obligations. (Hîncu, 2015b).Social responsibility covers ethical behaviour in the workplace, in the market or community. Costa contribution to society, can bring benefits for travel companies ensuring long-term competitiveness (Roman, Stanciu, Condratov, 2008)

\section{Promoting the „Bucovina, tourism brand}

\section{Components and benefits of the "Bucovina" brand}

The benefits of a successful tourism branding for Bucovina are:

1) It differentiate the Bucovina tourism product of other products in a unique way, relevant and motivating for potential customers. It provides added value.

2) It increases the value perception of the product by boosting and supporting the sales price of global tourism products related to Bucovina (e.g. religious tourism circuits of pilgrimage-type, active tourism holiday packages, and tourist packages at hotels or hostels in the area).

3) It provides the possibility of launching new products much faster and more cost efficiently.

Bucovina is a tourist destination within the Romania tourism macroproduct. Thus, in the case of foreign tourists performing a voyage of 10 days in our country, Bucovina area is usually assigned 2 days. 


\section{The brand creation process}

Creating a Bucovina tourism brand must take into account the need to be a complete product, including:

- visits to cultural sites (monasteries, museums, churches, castles etc.).

- spa treatment.

- Sports tourism (hunting and fishing, paragliding, mountain-biking and trekking).

- Rest and recreation tourism.

- Rural tourism included in several optional programs.

In order to be able to retain tourists in the area for more than 2 days additional attractions outside monasteries should be designed, for example, setting ski slope in Gura Humorului (Ariniş), Câmpulung, Vama, Botuş, promoting the adventure tourism (e.g. boating on the Bistrița river, climbing, paragliding and mountain biking).

In terms of building housing facilities (activity that has increased lately), we believe that the traditional architecture should prevail in these buildings, both inside and outside to create a special atmosphere of the area.

We consider it necessary to provide a customized common offer for the tourist housing facilities in Bucovina. Such an offer should include travel programs, allowing tourist accommodation for 6 nights in the area. Such an offer should contain combined proposals and a variety of programs for hunting and fishing, hiking, horse riding, mountain biking, visits to the sheepfold, climbing, paragliding etc. To facilitate the provision of tourism programs for Bucovina it is necessary to create an effective communication between representatives of travel agencies and the reception structures (hotels, villas, hostels etc.).

Such initiatives are already in place. Thus, a number of agencies in Suceava conceived adventure tourism programs, which offers but did not wake until the moment interest.

Among the tourist activities that should be developed and promoted there are:

- Theme programs (hikes) that can be organized due to the existence in this area of numerous trails. Among them some are worth mentioning: the old „Drum al tătarilor” ("Road of the Tatars”) up to the Cârlibaba locality and its other end leading to the Moldovița

Hincu, L. (2015). Ethics - a Form of Marketing for the Tourism Brand of Bucovina. Logos Universality Mentality Education Novelty, Section: Economical and Administrative Sciences, II (1), 25-37. Doi: http://dx.doi.org/10.18662/lumeneas.2015.0201.03 
Monastery. These trails can be traveled on foor or using horses that locals can provide for tourists.

- Riding programs: horse riding can be practiced at the stud in the town of Rădăuți and the on in the locality of Lucina. Tourists can appreciate the value of race horses at the manege arranged on site.

- Programs such as „Acasă la meşteri populari” ("Among artisans and craftsmen") consisting of visiting their workshops (one of them even provides tourist accommodation).

The Bucovina brand promotion program must consider two main objectives:

- Presenting in a most attractive way of the advantages for the tourists who visit this region.

- Creating a good reputation for the tourist services in this region.

To facilitate the visitors' information about the locations of attractions of Bucovina we believe it is essential to create a network of tourist signalling. In this respect, the following must be defined:

- the information to be provided (maps, viewing of the sightseeing locations and accommodation facilities, the direct contact addresses thereof) and the languages in which it will be provided;

- the levels of information (entry into the territory, the mentioned areas);

- The precise location of tourist information centers;

- The aesthetics of the panels, graphic standards and materials used;

- Organizing the implementation and maintenance of these panels.

In conclusion, we can say that a particularly important element within tourism companies is the ethics and deontology and therefore we believe that the subject whom we have tried to outline is of paramount importance. Whether we are talking about the discovery of new things, new cultures, other landscapes, tourism has emerged from the need of the individual to relax or to spend pleasant and quality time away from the daily activities of daily life. Bucovina is a tourist destination within the ROMANIA tourism macroproduct and an area of international interest in cultural-historical and religious heritage due to the natural conditions of great landscape value. The tourism potential of the region provides the possibility of developing an exceptionally sharp tourism sector which can be a source of significant economic growth in the coming years. All the staff 
working in the tourism industry and not only must observe certain principles, codes of professional ethics in dealing with customers, to take account of these ethical principles for the success on the national and international market. The fairness, perseverance and the continuous care for the clients and the quality of tourism products and services offered are just some of the ethical principles to be observed to attract more customers and hence to increase profit and turnover of the tourism companies. So we believe that any company seeking to maximize profits must first establish a code of professional ethics. In order to be successful on the national and international tourist market, it is paramount to create a tourist brand to be promoted on-line or through other advertising mediums.

\section{References}

Hîncu, L. (2015a). Promoting touristic brand Bucovina. Management Intercultural, XVII, 1(33), 241-243.

Hîncu L. (2015b). Ethics in tourism companies in our country. Logos Universality Mentality Education Novelty, Section: Philosophy and Humanistic Sciences, III(1), 71-81.

Nedelea, A. (2003). Politici de marketing. București: Editura Didactica şi pedagogica.

Nedelea, A. (2009). Strategii si politici de marketing in cazul produsului touristic Bucovina. Universitatea ,SStefan cel Mare” Suceava.

Sandu, A. (2012). Etică şi deontologie profesională. Iaşi: Ed. Lumen.

T,igu, G. (2003). Etica afacerilor în turism-Puncte de vedere, cazuri, teme de reflecție. Bucureşti: Ed.Uranus.

Roman, C., Stanciu, P., Condratov, I. (2008). Factorul uman în turismul durabil, între etică şi responsabilitate social. Amfiteatrul Economic, 23, 210-218.

\section{Biodata}

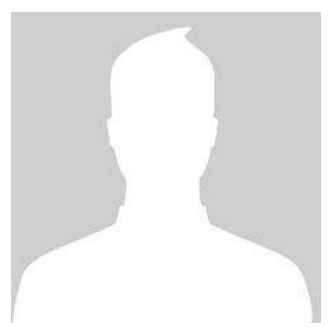

\section{Teacher Liliana HîNCU}

Liliana Hîncu has graduated from The Faculty of Economics and Public Administration of Stefan cel Mare University of Suceava. She is a specialist in the management of trade, tourism and services companies. In present she is teacher of tourism at College 
„Andronic Motrescu” the town of Rădăuți, area Suceava. She has participated in workshops and round table conferences. She is currently developing the idea of marketing in tourism.

Hincu, L. (2015). Ethics - a Form of Marketing for the Tourism Brand of Bucovina. Logos Universality Mentality Education Novelty, Section: Economical and Administrative Sciences, II (1), 25-37. Doi: http://dx.doi.org/10.18662/lumeneas.2015.0201.03 